\title{
Study on Risk Identification and Key Risks of Prefabricated Building Supply Chain Based on Grounded Theory
}

\author{
Shiyong Chai ${ }^{1, *}$, Minghui Liu ${ }^{1}$, Zhipeng Zhang ${ }^{1}$ and Suyue $\mathrm{Li}^{1}$ \\ ${ }^{1}$ Department of Engineering Management, Business School, Hohai University, China.
}

\begin{abstract}
Supply chain management is an important challenge faced by prefabricated buildings. The transfer of prefabricated modules will inevitably be accompanied by the transmission and diffusion of risks. It is precisely because of the inherent characteristics of the prefabricated building supply chain risks that the current prefabricated building completion rate is low. Based on this, the Grounded Theory is used to identify the risks of prefabricated construction projects from the perspective of the supply chain, and build a full-stage risk system; and introduce the Interpretation Structure Model Theory to analyze the interrelationship between risk factors, and obtain different risk levels; finally, specific risk control measures are proposed for deep-seated factors, which provide new ideas for the development of prefabricated buildings.
\end{abstract}

\section{Introduction}

In 2020, Corona Virus Disease 2019 broke out globally. During the fight against the epidemic, the Huoshenshan and Leishenshan hospitals, which were completed and put into use within 10 days, played a vital role in quickly responding to the epidemic and treating patients. The use of "steel box-type house assembly construction" is an important technical support for the rapid construction of the hospitals. As a new construction and production method, the prefabricated construction not only provides new ideas for the country to quickly respond to similar emergency situations in the epidemic, but also has a shorter construction period, high efficiency, energy saving and environmental protection compared with traditional cast-in-place buildings. The benefits to society, economy and environment are significant. However, according to the latest data, 420 million square meters of newly constructed prefabricated buildings nationwide were started in 2019, accounting for approximately $13.4 \%$ of the newly built building area [1] The development of prefabricated buildings faces many challenges and problems in the actual application process.

As shown in Fig.1, International knowledge domains related to prefabricated building research can be divided into "Greenhouse Gas Emissions(\#0)", "Affecting Prefabricated Construction Promotion(\#1)", "Prefabricated Modular Units(\#2)", "Prefinished Volumetric Construction(\#3)", "Prefabricated Construction Supply Chain Management (\#4)", "Steel Beam(\#5)", "Modern Method(\#6)", "Using Largediameter Reinforcing Bars(\#7)", "Assemblies Installation(\#13)" etc. It can be seen that "prefabricated building supply chain management" (\#4) is currently a hot research topic. With the development of prefabricated buildings, domestic scholars have carried out many studies. Jiang [4] showed that the reason for the long-term stagnation of prefabricated structures is the lack of professional research on the integrity of prefabricated structures and the design and construction management. Liao [5] analyzed the problems existing in the development of prefabricated buildings from the perspective of green buildings, and found that the existing policy support is insufficient and industrial management is not perfect. Zhai [6] and other studies have shown that the low degree of supply chain integration, the inability to freeze the design in the early stage, the high cost, the lack of supporting policies and related standards are the main factors restricting the development of prefabricated buildings in China. However, most domestic researches focus on phased research on risk identification, assessment and management countermeasures in a certain dimension of prefabricated construction projects, such as production, design, construction research, practical application research, performance, quality and cost research, etc. It is rare to conduct risk analysis on the whole process of the supply chain, and form a systematic and structured risk model.

Prefabricated construction is a mode that part of the work of on-site is moved to the factory. After professional design, prefabricated modules and components are processed by large-scale production methods, and then the components are transported from the factory to the site for assembly. This is a traditional two-echelon supply chain (factory $\rightarrow$ off-site) [3]. The transfer of modules will inevitably be accompanied by the transmission and diffusion of risks, which exist in all

* Corresponding author: 461632107@qq.com

(c) The Authors, published by EDP Sciences. This is an open access article distributed under the terms of the Creative Commons Attribution License 4.0 
stages of prefabricated construction projects and ultimately act on the main body of the project. Therefore, this article uses grounded theory to analyse the interview results and literature, extracts prefabricated building supply chain risks in depth and scientifically, builds a risk system at all stages of the supply chain, to a certain extent, overcomes the divergence between traditional qualitative research and quantitative research, and finally leads to the depth of results. Validity, standardization, and reliability are greatly improved. And with the help of the Interpretation structure model to analyse the relationship between risks, explore the root causes and action paths of risks, decompose complex system problems into multi-level structures that are convenient for understanding and analysis. Finally provide reference for construction companies in the process of adopting the prefabricated construction mode, and promote the sustainable development of the prefabricated construction industry.

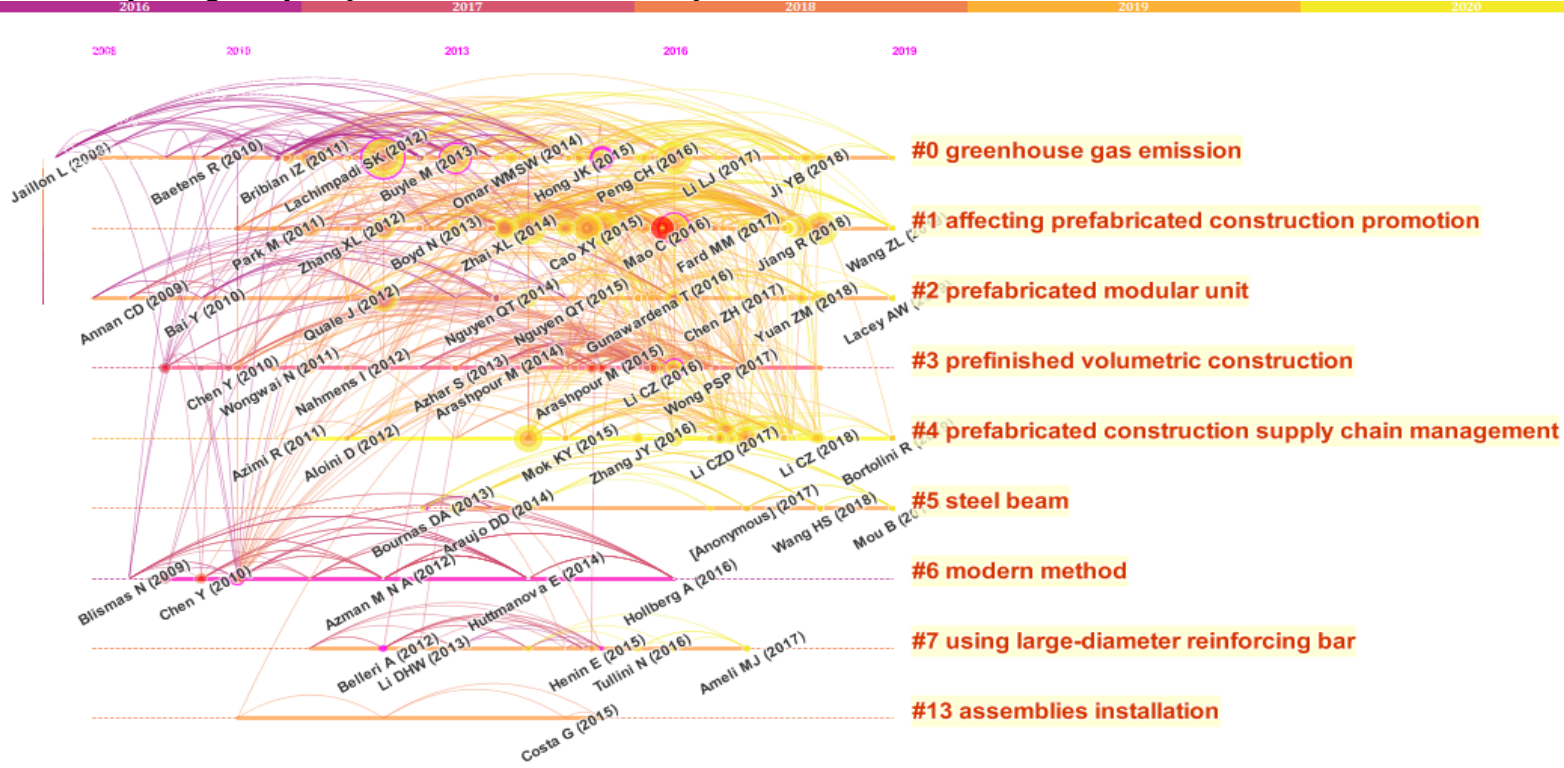

Fig.1. Timeline View

\section{Risk Identification of Prefabricated Building Supply Chain Based on Grounded Theory}

Grounded Theory is a bottom-up qualitative research method. It was jointly proposed by two Columbia University sociologists, Glaser and STRAUSS, in 1967. It aims to collect a large amount of literature and interview data through a gradual process. Researchers can construct qualitative research theories Model through open coding, axial coding, and selective coding[7]. The significance of grounded theory lies in the ability to abstract conceptual categories and their internal connections without research hypotheses. Based on this, this study collects original data through literature retrieval and expert interviews, and uses Nvivo 11 software to identify risk factors in the supply chain of prefabricated buildings. The analysis process is shown in Figure 2. 

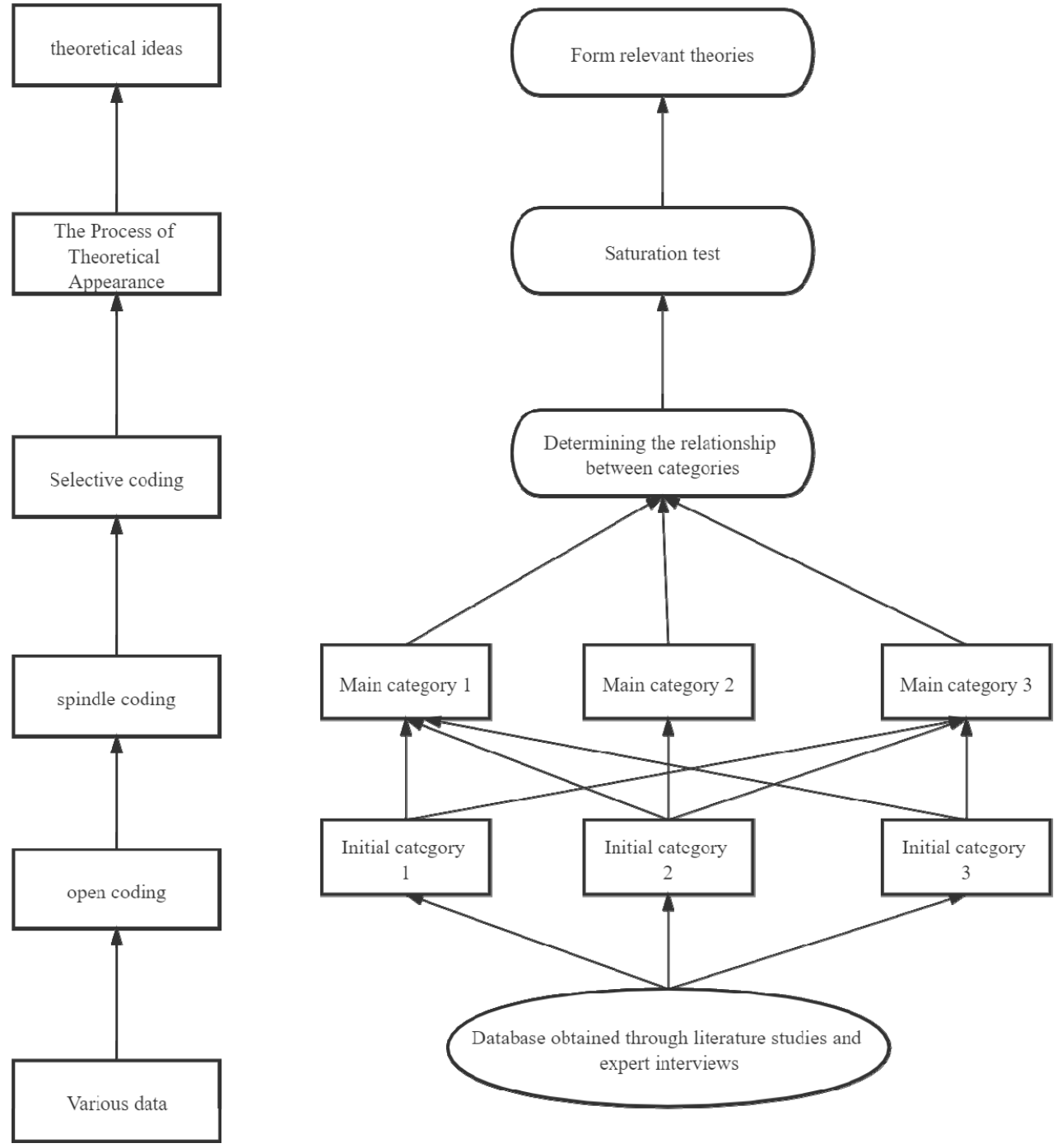

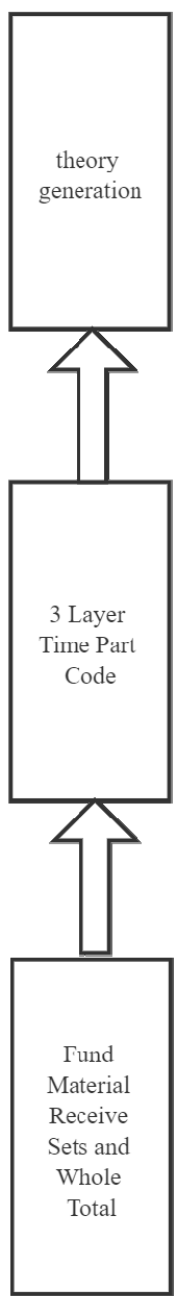

Fig.2. Grounded Theory Analysis Process

\section{1 data collection}

This study uses literature research and semi-structured interviews to collect data, with inteview results as the mainstay, and literature data as a supplement. Nantong is a well-known "town of construction" in China, and its prefabricated construction industry is also at the forefront of China. The interview was conducted with 14 experts and scholars in the field of prefabricated buildings from the Nantong Institute of Prefabricated Buildings and Intelligent Structures, and conducted field research on the prefabricated building construction site, transportation process, construction and manufacturing in advance, so as to formulate a scientific interview Outline to filter out risk factors. The interview content and target information are shown in Table 1 and Table 2.

On the basis of interviews, supplemented by literature materials, through CNKI, searched journals with the theme of "prefabricated building" from 2016 to 2020 , and a total of 424 documents were searched; through WOS (Web Of Science), searched on the subject of "assembly supply chain" in the past five years, and a total of 412 articles were published. Combining the content of the literature and the research direction, after cleaning, the articles with large differences in content were eliminated, and a total of 35 articles were screened out. Thirty articles are randomly selected as main shaft codes, and the remaining 5 articles are reserved for theoretical saturation test. 
Table.1. Interview Outline

\begin{tabular}{|c|c|}
\hline Interview theme & Outline content \\
\hline $\begin{array}{l}\text { The basic information of } \\
\text { respondents and their experience } \\
\text { in participating in prefabricated } \\
\text { buildings }\end{array}$ & Gender, Name, Area, Unit Participating in Prefabricated Building Projects and Status \\
\hline $\begin{array}{ll}\text { Risk factors } & \text { of prefabricated } \\
\text { buildings } & \text { proposed by } \\
\text { respondents } & \text { under different } \\
\text { assumptions } & \end{array}$ & $\begin{array}{l}\text { 1. Assuming that you are in the construction unit, what factors or risks do you think hinder you from } \\
\text { adopting prefabricated buildings? } \\
\text { 2. Assuming that you are in the design unit, what difficulties do you think may be encountered in the } \\
\text { design of prefabricated components? } \\
\text { 3. Assuming that you are in the design unit, what difficulties do you think may be encountered in the } \\
\text { design of prefabricated components? What are the risks? } \\
\text { 4. Assuming that you are in the production unit, what difficulties do you think may be encountered in } \\
\text { the production of prefabricated components? What are the risks? } \\
\text { 5. Assuming that you are in the transport unit, what difficulties do you think may be encountered in } \\
\text { the transport of prefabricated components? What are the risks? } \\
6 \text {. Assuming that you are in the installation unit, what difficulties do you think may be encountered } \\
\text { in the installation of prefabricated components? What are the risks? } \\
\text { 7. What part of the supply chain, such as design, production, transportation, installation, has the } \\
\text { greatest risk or the weakest market? } \\
\text { 8. Do you think that the current assembly building supply chain industrial chain system is complete } \\
\text { enough? What do you think is the biggest problem in the development of prefabricated buildings? }\end{array}$ \\
\hline $\begin{array}{l}\text { Questionnaire on Risk } \\
\text { Assessment of Assembly } \\
\text { Building Supply Chain }\end{array}$ & $\begin{array}{l}\text { 1. Type of work unit. } \\
\text { 2. Do you think prefabricated buildings will become the mainstream of future architectural } \\
\text { development? } \\
\text { 3. Your working years in engineering ( including scientific research ) are ? } \\
\text { 4. With regard to the current status of prefabricated construction, is your organization more inclined } \\
\text { to construct prefabricated construction projects? } \\
\text { 5. Which type of construction form do you think is more promising for residential buildings? } \\
\text { 6. What do you think are the main obstacles restricting the development of prefabricated buildings? } \\
\text { 7. Supply chain risk assessment. } \\
\text { 8. Do you have anything to add to the risk factors of prefabricated building supply chain? } * \\
\text { 9. Do you have any suggestions on how to avoid the risk of assembly building supply chain? }\end{array}$ \\
\hline
\end{tabular}

Table 2. Basic information of interviewees

\begin{tabular}{|c|c|c|c|}
\hline Serial number & Sexuality & Occupation & Areas \\
\hline R01 & males & manager & $\begin{array}{l}\text { Research and Development of Concrete } \\
\text { Components }\end{array}$ \\
\hline R02 & males & manager & steel construction system \\
\hline R03 & males & manager & PC components \\
\hline R04 & males & manager & Steel structure accessories system \\
\hline R05 & female & designer & construction design \\
\hline R06 & males & designer & construction design \\
\hline R07 & males & driver & logistics transportation \\
\hline R08 & males & engineer & Installation and assembly \\
\hline R09 & female & university teacher & science research \\
\hline $\mathrm{R} 10$ & males & university teacher & science research \\
\hline R11 & males & postgraduate & science research \\
\hline R12 & males & doctoral students & science research \\
\hline $\mathrm{R} 13$ & female & doctoral students & science research \\
\hline $\mathrm{R} 14$ & males & doctoral students & science research \\
\hline
\end{tabular}

\subsection{Decoding process}

\subsubsection{Open Coding}

Open coding is a process of extracting concepts from the original sentences based on the understanding and induction of the original data and interview results, and then re-integrating the concepts into categories. Through the textualization of literature and interview results, and screening and filtering sentences with unclear semantics and researching inconsistent sentences, 107 original sentences were finally obtained, and 17 effective concepts were summarized. Through refining understanding and constant comparison, the concept is finally refined into 16 initial categories, which are risk factors affecting the supply chain of prefabricated buildings. Some representative original sentences, conceptualization and categorization results are shown in Table3. 
Table 3. Open coding process

\begin{tabular}{|c|c|c|}
\hline Initial category & Effective concept & Original sentence \\
\hline F1 Imperfect design & $\begin{array}{l}\text { Insufficient design } \\
\text { Incomplete drawing design }\end{array}$ & $\begin{array}{l}\text { "Deepening design is a very important part of prefabricated buildings. } \\
\text { After the design is completed, the risks of all links will be reduced a lot; } \\
\text { and the drawings need to be signed by the person in charge during the } \\
\text { design process, which is also convenient for better determination of } \\
\text { responsibilities." } \\
\text { "Improper management by the designer will have an impact on } \\
\text { product quality, product delivery time and construction convenience." }\end{array}$ \\
\hline F2 Design changes & $\begin{array}{l}\text { Frequent design changes } \\
\text { Irregular design process }\end{array}$ & $\begin{array}{l}\text { "There may be loopholes in the design plan that lead to design } \\
\text { changes." } \\
\text { "The design level of designers is low, and the design process is not } \\
\text { standardized and other factors will cause design changes, which will } \\
\text { adversely affect the final quality of the product, and even cause safety } \\
\text { accidents in serious cases." }\end{array}$ \\
\hline $\begin{array}{l}\text { F3 Unreasonable } \\
\text { design scheme }\end{array}$ & Poor feasibility of the design plan & $\begin{array}{l}\text { "Some design schemes can achieve the desired effect under ideal } \\
\text { conditions, but they do not consider the actual construction level and raw } \\
\text { material restrictions. They seem to be perfect, but in reality they are } \\
\text { difficult to achieve." }\end{array}$ \\
\hline $\begin{array}{l}\text { F4 Unqualified } \\
\text { component quality } \\
\text { control }\end{array}$ & $\begin{array}{l}\text { Equipment failure } \\
\text { Improper staffing } \\
\text { Insufficient technical level } \\
\text { Low quality of components }\end{array}$ & $\begin{array}{l}\text { "The materials purchased by the people who purchase concrete do not } \\
\text { meet the requirements, making the construction quality unqualified." } \\
\text { "The quality and safety of raw materials such as steel bars and } \\
\text { concrete before entering the construction site is affected by the supplier, } \\
\text { and these are most likely to become direct factors leading to safety } \\
\text { accidents during the construction process." } \\
\text { "The efficiency of the machine is not high, it cannot meet the } \\
\text { demand, the personnel arrangement is unreasonable, the skill of the } \\
\text { workers is not up to standard, and the production components are not } \\
\text { qualified." } \\
\text { "The quality risk of the components may lead to the risk of the entire } \\
\text { construction project, affect the entire construction process, and cause the } \\
\text { risk of short-term suspension or long-term shutdown. Therefore, } \\
\text { construction companies must strictly control the quality of materials, } \\
\text { especially for the secondary inspection of components when they enter the } \\
\text { construction site." } \\
\text { "Insufficient management level and untimely supply of material } \\
\text { suppliers will cause delays in the supply of products to production units } \\
\text { and low production efficiency." }\end{array}$ \\
\hline $\begin{array}{l}\text { F5Improper storage of } \\
\text { components }\end{array}$ & $\begin{array}{l}\text { Poor component storage } \\
\text { environment } \\
\text { Mismanagement }\end{array}$ & $\begin{array}{l}\text { "The storage of materials is affected by the environment, improper } \\
\text { management, moisture, wear, and corrosion will seriously affect the } \\
\text { quality of the construction." }\end{array}$ \\
\hline $\begin{array}{l}\text { F6 Limited supplier } \\
\text { selection }\end{array}$ & Less suppliers in emerging areas & $\begin{array}{l}\text { "Prefabricated construction is still an emerging field after all, with } \\
\text { fewer suppliers and fewer options." }\end{array}$ \\
\hline $\begin{array}{l}\text { F7 Uncertainty during } \\
\text { transportation }\end{array}$ & $\begin{array}{l}\text { Transportation accidents of } \\
\text { complex materials and } \\
\text { components on road conditions }\end{array}$ & $\begin{array}{l}\text { "Installation can be said to be the most important risk in the supply } \\
\text { chain, because someone will sign the design, but there are currently no } \\
\text { professional assembly-type installation technicians, and it is difficult to } \\
\text { find the direct person in charge if there is a problem; There are also driver } \\
\text { levels and road congestion on holidays." } \\
\text { "The transportation of materials and components is one of the } \\
\text { characteristics of the construction industry, which is different from other } \\
\text { industries. Due to the particularity of the materials, there will be certain } \\
\text { requirements for the transportation of materials and equipment. Can the } \\
\text { construction progress be carried out smoothly and whether the materials } \\
\text { can be delivered in time? Very important, especially for prefabricated } \\
\text { buildings, the distribution of prefabricated beams, columns and slabs } \\
\text { directly affects the construction process." }\end{array}$ \\
\hline $\begin{array}{l}\text { F8 Unreasonable } \\
\text { transportation plan } \\
\text { arrangement }\end{array}$ & $\begin{array}{l}\text { Design } \\
\text { Staff assignments } \\
\text { Equipment management } \\
\text { Material management } \\
\text { Progress Control }\end{array}$ & $\begin{array}{l}\text { "During the construction process, unreasonable personnel allocation, } \\
\text { improper use of equipment, improper schedule arrangements and other } \\
\text { management risk factors will cause the construction unit to lose profits and } \\
\text { delay the construction period." }\end{array}$ \\
\hline $\begin{array}{l}\text { F9 Transportation } \\
\text { restrictions }\end{array}$ & $\begin{array}{l}\text { There are restrictions on } \\
\text { component size, loading } \\
\text { technology, and vehicle selection }\end{array}$ & $\begin{array}{l}\text { "Prefabricated building components may be too large and have } \\
\text { peculiar shapes. The width of roads affects construction and } \\
\text { transportation; there are also certain restrictions on loading technology and } \\
\text { model selection." "The environment of construction projects is an } \\
\text { important factor for construction safety. The environment includes } \\
\text { Surrounding environment, operating environment, natural environment, } \\
\text { etc. Although environmental factors do not often cause safety problems } \\
\text { and rarely cause safety accidents, they also have certain impacts on the } \\
\text { construction of prefabricated buildings, and the operating environment has } \\
\text { a greater impact on safety." }\end{array}$ \\
\hline $\begin{array}{l}\text { F10 Poor quality } \\
\text { control during } \\
\text { installation }\end{array}$ & $\begin{array}{l}\text { There are bumps and wear when } \\
\text { the components are installed }\end{array}$ & $\begin{array}{l}\text { "During the hoisting process, bumps and wear are likely to occur, } \\
\text { which will affect the quality of the construction, and even result in } \\
\text { returning to the factory for redo." }\end{array}$ \\
\hline
\end{tabular}




\begin{tabular}{|c|c|c|}
\hline $\begin{array}{l}\text { F11 Installation of } \\
\text { mechanical equipment } \\
\text { maintenance or } \\
\text { improper operation }\end{array}$ & $\begin{array}{l}\text { Maintenance of tower cranes and } \\
\text { other mechanical equipment } \\
\text { Operating specifications }\end{array}$ & $\begin{array}{l}\text { "Because prefabricated buildings require a lot of large-scale } \\
\text { machinery and equipment, the risk factors of machinery and equipment } \\
\text { cannot be ignored. The influencing factors of mechanical equipment } \\
\text { include maintenance and maintenance of mechanical equipment, } \\
\text { standardization of tower crane lifting operation, tower crane layout, } \\
\text { mechanical equipment depreciation rate, mechanical equipment } \\
\text { depreciation rate, lifting load, selection of auxiliary spreaders, etc. " }\end{array}$ \\
\hline $\begin{array}{l}\text { F12 Poor quality of } \\
\text { installers }\end{array}$ & $\begin{array}{l}\text { Lack of training } \\
\text { Lack of qualifications }\end{array}$ & $\begin{array}{l}\text { "At present, there is a lack of professional system-trained installers in } \\
\text { the field of prefabricated buildings. Lack of qualifications will cause } \\
\text { installation errors, poor quality, and affect the quality of the building." }\end{array}$ \\
\hline $\begin{array}{l}\text { F13 Insufficient } \\
\text { supervision }\end{array}$ & $\begin{array}{l}\text { Wrong judgment, missed } \\
\text { judgment } \\
\text { Data authenticity }\end{array}$ & $\begin{array}{l}\text { "Risk of misjudgment and missed judgment. Due to the limitation of } \\
\text { sampling sample size and the random risk of sampling, the unqualified } \\
\text { batch is judged as qualified, or the unqualified batch is not detected. The } \\
\text { authenticity of raw material quality data, engineering inspection records, } \\
\text { acceptance records, and other internal engineering technical data directly } \\
\text { affects the authenticity of the safety evaluation of prefabricated building } \\
\text { construction." }\end{array}$ \\
\hline $\begin{array}{l}\text { F14 Low level of } \\
\text { information sharing }\end{array}$ & $\begin{array}{l}\text { Differences in market information } \\
\text { Information asymmetry }\end{array}$ & $\begin{array}{l}\text { "Sometimes there may be deviations in the interpretation of the } \\
\text { information when the upper-level information is passed to the lower-level. } \\
\text { For example, each region has its own interpretation of the requirements for } \\
\text { the assembly rate." } \\
\text { "If procurement managers do not understand the market conditions in } \\
\text { time, they will often increase procurement costs. Therefore, the difference } \\
\text { in market information and the asymmetry of information will affect the } \\
\text { entire procurement process of construction companies." }\end{array}$ \\
\hline F15 Safety incident & $\begin{array}{l}\text { Possible safety accidents during } \\
\text { transportation and installation } \\
\text { Unreasonable design may also } \\
\text { have security risks }\end{array}$ & $\begin{array}{l}\text { "Traffic accidents during transportation, over-height tower cranes } \\
\text { during installation, danger to construction personnel, etc. Unreasonable } \\
\text { design may also have potential safety hazards." }\end{array}$ \\
\hline $\begin{array}{l}\text { F16 The adverse } \\
\text { impact of the social } \\
\text { environment }\end{array}$ & Low degree of standardization & $\begin{array}{l}\text { "As an emerging industry, prefabricated buildings have a low degree } \\
\text { of standardization in many aspects." }\end{array}$ \\
\hline $\begin{array}{l}\text { F17 Adverse effects of } \\
\text { the social environment }\end{array}$ & $\begin{array}{l}\text { Influence of Construction } \\
\text { Engineering Environment, } \\
\text { Operation Environment and } \\
\text { Natural Environment }\end{array}$ & $\begin{array}{l}\text { "The environment of a construction project is an important factor for } \\
\text { construction safety. The environment includes the surrounding } \\
\text { environment, work environment, and natural environment. Although } \\
\text { environmental factors do not often cause safety problems and rarely cause } \\
\text { safety accidents, they also have a certain impact on the construction of } \\
\text { prefabricated buildings, and the operating environment has a greater } \\
\text { impact on safety." }\end{array}$ \\
\hline $\begin{array}{l}\text { F18 The impact of } \\
\text { national policies }\end{array}$ & $\begin{array}{l}\text { Policy changes } \\
\text { Capital control } \\
\text { Slow approval system and } \\
\text { complicated procedures }\end{array}$ & $\begin{array}{l}\text { "Specifications, manuals, and industry standards have limitations and } \\
\text { will need to be revised after a period of time." } \\
\text { "The government directly takes the lead in the construction of } \\
\text { prefabricated buildings, formulates policies and measures, creates a } \\
\text { relatively loose market environment, and can provide effective financial } \\
\text { support." } \\
\text { "The changes in the macro environment will have an impact on the } \\
\text { company's product market, raw material supply, profitability and quality." }\end{array}$ \\
\hline F19 Excessive cost & $\begin{array}{l}\text { Design cost } \\
\text { Manufacturing cost } \\
\text { Transportation cost } \\
\text { Construction cost }\end{array}$ & $\begin{array}{l}\text { "Cost control runs through the entire process of the prefabricated } \\
\text { building supply chain. Good cost control can greatly reduce costs and help } \\
\text { promote the development of prefabricated buildings." }\end{array}$ \\
\hline F20 Contract disputes & $\begin{array}{l}\text { Contract disputes between } \\
\text { enterprises }\end{array}$ & $\begin{array}{l}\text { "Contract disputes also go through the entire process of the } \\
\text { prefabricated construction supply chain. Reducing contract disputes is } \\
\text { conducive to friendly cooperation between the contracting parties and } \\
\text { achieving a win-win situation." }\end{array}$ \\
\hline $\begin{array}{l}2 \text { Axial Coding } \\
\text { al coding is ba }\end{array}$ & & $\begin{array}{l}\text { subcategories, The process of realizing relationalizat } \\
\text { and primary-secondaryization, so as to summarize } \\
\text { main category. With the help of the model, five } \mathrm{m} \\
\text { categories of design risk, manufacturing r } \\
\text { transportation risk, construction risk, and total risk h } \\
\text { been developed. }\end{array}$ \\
\hline
\end{tabular}
continuous comparison of the effective concepts and

Table 4. Spindle coding process

\begin{tabular}{ccc}
\hline Main category & Subcategory & Category connotation \\
\hline \multirow{3}{*}{ M1 Design risk } & Imperfect design & Insufficient deepening design or incomplete drawing design \\
\cline { 2 - 3 } & Design changes & $\begin{array}{c}\text { Frequent changes to the design drawings caused by changes in the owner's } \\
\text { needs or the mistakes of the designers }\end{array}$ \\
\hline
\end{tabular}




\begin{tabular}{|c|c|c|}
\hline & Unreasonable design scheme & $\begin{array}{l}\text { The designer did not comprehensively consider the raw materials, the } \\
\text { construction site environment, the level of construction personnel and other } \\
\text { factors, resulting in poor feasibility }\end{array}$ \\
\hline \multirow{3}{*}{$\begin{array}{c}\text { M2 } \\
\underset{\text { Manufacturing }}{\text { risk }}\end{array}$} & $\begin{array}{l}\text { Unqualified component quality } \\
\text { control }\end{array}$ & $\begin{array}{l}\text { Unqualified component quality caused by inadequate component quality } \\
\text { control }\end{array}$ \\
\hline & Improper storage of components & $\begin{array}{l}\text { Component damage caused by improper storage environment or improper } \\
\text { storage management }\end{array}$ \\
\hline & Limited supplier selection & Fewer suppliers in emerging fields make supplier choices limited \\
\hline \multirow{3}{*}{$\begin{array}{l}\text { M3 } \\
\text { Transportation } \\
\text { risk }\end{array}$} & $\begin{array}{l}\text { Uncertainty about the transport } \\
\text { process }\end{array}$ & $\begin{array}{l}\text { Uncontrollable road conditions and transportation accidents cause uncertainty } \\
\text { in the transportation process }\end{array}$ \\
\hline & $\begin{array}{c}\text { Unreasonable transportation plan } \\
\text { arrangement }\end{array}$ & $\begin{array}{l}\text { Unreasonable transportation plan arrangements cause transportation delays } \\
\text { and thus delays in construction schedules }\end{array}$ \\
\hline & Transportation restrictions & $\begin{array}{l}\text { There are restrictions on the selection of vehicles caused by the size, shape } \\
\text { and loading technology of the components }\end{array}$ \\
\hline \multirow{3}{*}{$\begin{array}{l}\text { M4 Construction } \\
\text { risk }\end{array}$} & $\begin{array}{l}\text { Poor quality control during } \\
\text { installation }\end{array}$ & $\begin{array}{c}\text { The quality of components caused by bumps and wear during the installation } \\
\text { process is seriously degraded }\end{array}$ \\
\hline & $\begin{array}{l}\text { Installation of mechanical } \\
\text { equipment maintenance or } \\
\text { improper operation }\end{array}$ & $\begin{array}{l}\text { Equipment damage caused by improper equipment maintenance or improper } \\
\text { operation by construction personnel }\end{array}$ \\
\hline & Poor quality of installers & $\begin{array}{l}\text { Installation errors caused by lack of ability of the installers affect the quality } \\
\text { of the building }\end{array}$ \\
\hline \multirow{8}{*}{$\begin{array}{l}\text { M5 Common } \\
\text { adventure }\end{array}$} & Insufficient supervision & $\begin{array}{l}\begin{array}{l}\text { Misjudgments and omissions caused by insufficient supervision on the } \\
\text { construction site }\end{array}\end{array}$ \\
\hline & $\begin{array}{l}\text { Low level of information sharing } \\
\text { and poor communication }\end{array}$ & $\begin{array}{l}\text { The low level of information sharing between upstream and downstream } \\
\text { enterprises and poor communication have adversely affected the entire } \\
\text { construction process }\end{array}$ \\
\hline & Safety incident & Safety accidents during manufacturing, transportation, and construction \\
\hline & $\begin{array}{l}\text { Adverse effects of the social } \\
\text { environment }\end{array}$ & $\begin{array}{l}\text { The continuous changes in the social environment have caused the } \\
\text { standardization of the entire construction process to continue to change } \\
\text { accordingly }\end{array}$ \\
\hline & $\begin{array}{l}\text { Adverse effects of natural } \\
\text { environment }\end{array}$ & $\begin{array}{l}\text { The natural environment of the construction site directly determines the } \\
\text { design, and the surrounding environment and operating environment will } \\
\text { affect manufacturing, transportation and construction }\end{array}$ \\
\hline & Impact of national policies & $\begin{array}{c}\text { Changes in the entire industry caused by changes in national policies caused } \\
\text { by changes in the macro environment }\end{array}$ \\
\hline & Excessive cost & $\begin{array}{l}\text { Including design cost, manufacturing cost, transportation cost, construction } \\
\text { cost and other costs }\end{array}$ \\
\hline & Agreement disputes & $\begin{array}{c}\text { Contract disputes between enterprises due to the boundaries of rights and } \\
\text { responsibilities or interest disputes }\end{array}$ \\
\hline
\end{tabular}

\subsubsection{Selective Coding}

As the last link of grounded theory coding, selective coding has the function of structuring and nucleating the initial category and the main category. Through the analysis, comparison, summary, and induction of the original text data, 16 initial categories, and 5 main categories, the core category of "factors affecting the realization of prefabricated building goals" that can connect all the main categories is obtained. Design, manufacturing, transportation, and construction are all links of the supply chain. From component design and drawing perfection, to component production level and quality control, to transportation and loading, and installation of tower cranes, all affect the realization of prefabricated building goals. Therefore, "factors affecting the realization of prefabricated building goals" can be used as a fishing line to guide the story line [8].

\subsubsection{Theoretical saturation test: test of reliability.}

It is the moment when the analyst can no longer develop a new category through alternate collection and continuous analysis of comparative data [9]. Reencoding the five reserved texts with three levels of coding did not result in a new category that acts outside the core category. Therefore, it can be concluded that the above model has reached a theoretical saturation state.

\section{Analysis of Key Risks in the Supply Chain of Prefabricated Buildings Based on Interpretive Structure Models}

Establish an expert group and use Delphi Technique to judge the direct causal relationship between risk factors. When $75 \%$ of the experts believe that there is a direct 
relationship between the two factors, the judgment is valid. The results are shown in Table 6.

Table 5. Risk Factors of Prefabricated Construction Supply Chain

\begin{tabular}{ll|ll}
\hline factor & direct acting factor & factor & direct acting factor \\
\hline$F_{1}$ & $F_{2}, F_{4}, F_{10}, F_{15}, F_{20}$ & $F_{11}$ & $F_{10}, F_{15}, F_{19}$ \\
$F_{2}$ & $F_{6}, F_{8}, F_{19}, F_{20}$ & $F_{12}$ & $F_{10}, F_{11}, F_{15}$ \\
$F_{3}$ & $F_{1}, F_{4}, F_{6}, F_{9}, F_{10}$, & $F_{13}$ & $F_{10}, F_{15}$ \\
$F_{4}$ & $F_{9}, F_{10}, F_{15}, F_{19}$ & $F_{14}$ & $F_{1}, F_{2}, F_{10}, F_{19}$ \\
$F_{5}$ & $F_{4}, F_{15}, F_{19}$ & $F_{15}$ & -- \\
$F_{6}$ & $F_{19}$ & $F_{16}$ & $F_{6}, F_{19}$ \\
$F_{7}$ & $F_{15}$ & $F_{17}$ & $F_{7}, F_{10}, F_{19}$ \\
$F_{8}$ & $F_{7}, F_{19}$ & $F_{18}$ & $F_{2}, F_{6}, F_{16}, F_{19}$ \\
$F_{9}$ & $F_{19}$ & $F_{19}$ & -- \\
$F_{10}$ & $F_{15}, F_{19}$ & $F_{20}$ & -- \\
\hline
\end{tabular}

\subsection{Risk mechanism analysis and control measures}

\subsubsection{Analysis on Risk Mechanism of Prefabricated Building Supply Chain}

With the help of the ISM operating program, the reachability matrix is divided into levels by reachability set, antecedent set, and common set, and the explanatory structure model of the prefabricated building supply chain risk is obtained. Finally, the class hierarchy is shown in Figure 3. The 6 levels can be divided into three groups according to the number of factors and their arrangement characteristics: direct factor group (level 1), indirect factor group (level 3 to 5) and deep factor group (level 6).

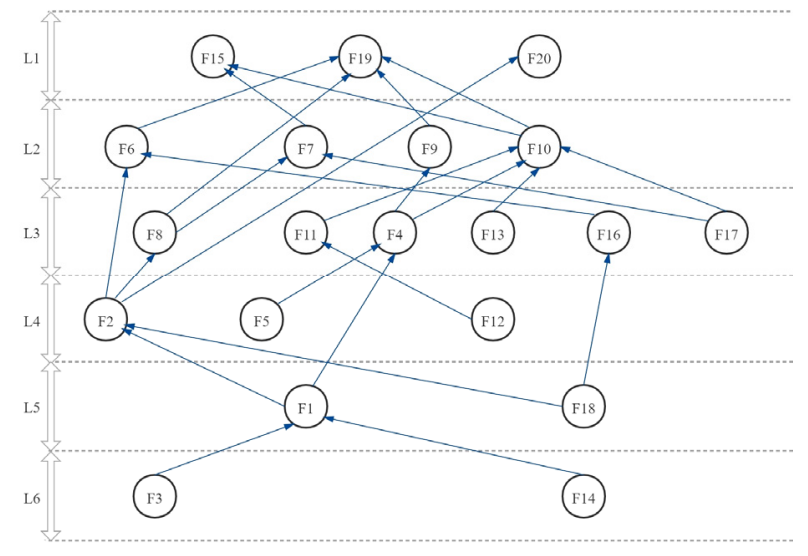

Fig.3. ISM Diagram of Risk Factors in Prefabricated Building Supply Chain

Indirect factors play a role in promoting direct factors, and at the same time, they are affected by deep-seated factors, which are important medial risks in the hierarchical structure. The indirect factors include design risks, manufacturing risks, transportation risks, construction risks and risks at all stages of the whole process, which constitute the complexity of the supply chain network.

The direct factors belong to the whole process risk: F15(safety accident), F19(excessive cost) and F20(contract dispute); these factors directly affect the supply chain, and strong direct control should be adopted.

For the deep factor group, the factors included are design risk factors: F3(Unreasonable design scheme); the whole process risk: F14(Low level of information sharing). The low level of information sharing not only means the lack of cooperation between the participants in the supply chain, but also affects the quality of the product. Due to the information asymmetry between the upstream and downstream, errors will occur in many aspects of the product, such as the product design manufacturer's response to the product. If the details require information not to be shared, it will lead to product quality problems, which in turn will lead to safety accidents. Therefore, the low degree of information sharing is a major factor that needs attention. Building Information Model (BIM) is a shared knowledge resource, and its greatest application value lies in the sharing and transmission of model information. Promoting the effective application of BIM during project implementation will greatly improve the quality and effectively promote the development of prefabricated buildings. The deep factor group risk occurs by influencing other risk factors, leading to a series of risk factors being affected. These factors are usually at the bottom of the model and are the most fundamental factor affecting the prefabricated building supply chain [10]. 


\subsubsection{Key risk factors and control measures}

In the prefabricated building supply chain risk factor ISM, fundamental factors will have effects on indirect factors, and then eventually trigger direct factors[11]. In order to ensure and improve the effective and normal implementation of prefabricated construction projects, the prevention and control of fundamental factors should be more important, and reasonable risk control measures should be formulated. The specific measures are as follows:

A) Strictly control the rationality of the design plan.

For prefabricated construction projects, design is the first link of the entire supply chain. Ensuring the quality of the design is the first pass to improve the overall quality of the building. The design unit must not only avoid reasons such as self-understanding and inadequate standard understanding, but also have to communicate with the owner to determine the various needs and maximum budget[12]. Putting the design risk control in place can reduce the occurrence of indirect risks and improve building efficiency.

B) Create a reliable information sharing system.

The prefabricated construction project has multiple levels of participants and multiple channels, and the efficiency of information transmission is low, which is easy to cause information pollution and information distortion [13]. If the building information model BIM can be effectively applied in the project implementation process, the quality of the prefabricated buildings will be greatly improved. With great information communication ability to ensure that better information transmission can be achieved at all stages of the prefabricated building supply chain, can the project be completed on schedule and with high quality.

\section{Conclusion}

1)After sorting out interview data and related literature, based on the grounded theory method, 20 risk factors of the prefabricated building supply chain were identified. The risk factors were screened by the Delphi method, and the whole stage risk system of the supply chain was constructed, and based on the ISM model. A hierarchical transition model of risk factors is established, and the mechanism and path of influence of risk factors are clarified.

2) Through the analysis of the hierarchical transfer model, it is found that the direct risk factors affecting the prefabricated construction project are safety accidents, high costs and contract disputes, and the deep-level risk factors are the unreasonable design plan and the low degree of information sharing. Different factors will affect each other, and then affect the stability of the system. Emphasis on deep-level key risk management and control can effectively improve construction efficiency.

\section{References}

1. The action plan of ' 13th Five-Year ' prefabricated building next year accounted for more than $15 \%$ of the new construction proportion $[\mathrm{J}]$. Commodity concrete, 2019 (12): 14.

2. 2019 Development of Prefabricated Buildings [N]. China Building Materials Journal, 2020-05-25.

3. D. Aloini, R. Dulmin, V. Mininno, et al. Supply chain management: a review of implementation risks in the construction industry[J]. Business Process Management Journal, 2012, 18(5).

4. Q.J. Jiang., Overview of the development of prefabricated concrete buildings at home and abroad [J]. Construction technology, 2010,41 (12): 10741077.

5. L.P. Liao., Development Status and Strategy of Green Prefabricated Building [J]. Enterprise Economy, 2019, (12).

6. X. Zhai, R. Reed., A. Mills., Factors impeding the offsite production of housing construction in China: an investigation of current practice[J]. Construction Management and Economics, 2014, 32(1-2): 40-52.

7. X.M. Chen., The ideas and methods of grounded theory $[\mathrm{J}]$. Educational research and experiment, 1999 (04): $3-5$.

8. X.J. Du., H. Liu., Research on the identification of key risks of Chinese enterprises overseas mergers and acquisitions based on grounded theory [J]. Management Review, 2012,24 ( 04 ): 18-27.

9. X.D. Fei., Grounded theory methodology: elements, research procedures and evaluation criteria [J]. Public administration review, 2008 (03) : 23-43.

10. L.L. Song., Q.M. Li., Y. Lu., etc., Study on factors influencing vulnerability of urban subway system $[\mathrm{J}]$. China Journal of Safety Science, 2016,26 (05): 6469.

11. P.C. Xiang., Y.H. Sheng., Research on social risk of major overseas infrastructure investment projects based on ISM [J]. Engineering Management Journal, 2020, 34 (04): 10-15.

12. F.S. Gao., Y. Zhou., Common problems and countermeasures in architectural engineering design [J]. Dwellings, 2020 (13): 80.

13. F.R. Ning., K. Xu., Communication and management of internal information in construction enterprises $[\mathrm{J}]$. Science and technology information, 2008 (32): 104-14 